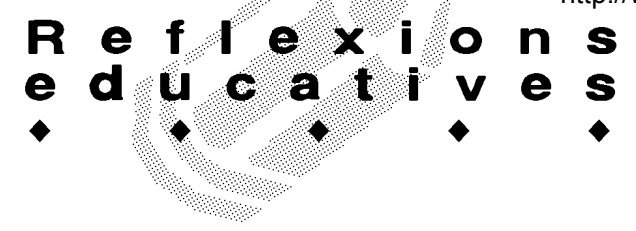

\title{
REPRESENTACIÓ DEL MÓN I CONFLICTE MORAL
}

\author{
Gabriel Janer Manila. Àrea de Teoria i Història de l'Educació. Universitat de les Illes Balears
}

Aquest text que comences a llegir constitueix el cos de les paraules d'homenatge a la Dra. Joana Noguera, catedràtica de Teoria i Història de l'Educació a la universitat Rovira i Virgili; paraules que vaig dir a la sala d'actes del campus Sescelades de la URV el passat 28 d'octubre del 2006, amb motiu de la celebració de la seva jubilació.

\section{La capacitat d'inventar històries}

Segurament una de les conquestes humanes que defineix amb més guany el pas cap a l'hominització és la capacitat dels homes d'inventar històries. Potser són abans la recerca del foc, l'aparició del llenguatge articulat, el descobriment que la tècnica, ni que sigui la utilització d'un garrot d'ullastre, multiplica el poder de les mans. Al costat d'aquestes grans conquestes, no em sé estar de situar-hi l'home que narra una història i inventa en la contança un món de ficció, relats que expliquen la mentida que la ment organitza i la paraula recrea. També és una ficció el discurs històric. A vegades els historiadors han cregut que era possible representar amb fidelitat el retrat d'una època, però avui sabem fins a quin extrem en la construcció del discurs històric intervenen les mateixes formes que governen l'escriptura de ficció, les formes literàries a través de les quals s'estructura el discurs de la Història: figures i recursos que són propis de l'escriptura narrativa, relacionada amb la representació de la realitat (CHARTIER, 1993). Llavors, el passat sobreviu com a signe, i com a signe atreu cadenes d'interpretacions. Cadenes de representacions que tracten d'imprimir marques de significat a l'experiència (SPIEGEL, 1993).

Només aprenem les coses que hem estat capaços de contar-nos, d'ordenar en una seqüenciació, d'estructurar en funció d'un relat. Si l'experiència no s'emmarca en una estructura narrativa, es perd en la memòria. Recontar l'experiència suposa ordenar-la, organitzar-la en una representació. El filòsof John Dewey havia dit que el llenguatge és un procediment que ens permet classificar i organitzar allò que sabem del món. Però només sabem allò que som capaços de representar, alhora que confegim el sentit de la representació.

\section{Característiques de la narració}

La força del relat consisteix a representar personatges, descriure situacions, comprometre'ns en unes determinades emocions. Mostrar, molt més que demostrar. Avui les ciències humanes han descobert que la narració és una nova manera de coneixença. També el significat de l'experiència està profundament determinat per l'ordre amb què n'hem organitzat la seqüenciació. Ben aviat els nins aprenen quelcom de prodigiós: que el sentit de les coses que fan -de l'experiència-, està profundament afectat per la manera en què són capaços de contar-les. J. Bruner (1991) ha escrit que la nostra capacitat per contar l'experiència en forma de relat no és únicament un joc, sinó també un instrument que utilitzam per conferir significat. I es tracta d'una estratègia que domina gran part de la vida de les cultures: des del sol-liloqui que ens relatam a l'hora d'adormir-nos fins a l'acusat que confessa i justifica la seva implicació en el delicte. La representació del món -l'estructuració de l'experiència en una seqüenciació narrativa: la forma en què bastim la ficció de la realitat- és el resultat d'un conflicte moral; perquè l'atribució de sentit és sempre el resultat d'un procés mitjançant el qual es creen i es negocien els significats a l'interior d'una cultura.

Llavors ens interessa escatir de quina manera els nins, des de ben petits, entren en aquest joc de significats i com aprenen a atribuir sentit, especialment sentit narratiu, al món que els envolta. He de dir que la tendència dels éssers humans a compartir històries que representen l'experiència múltiple dels homes, i a confegir interpretacions congruents amb els diversos compromisos morals que estableix una determinada societat, és una de les formes més poderoses d'estabilitat i cohesió social.

L'home capaç de narrar-se és l'home capaç d'actuar, de sotmetre's a normes, d'esdevenir un subjecte moral. Sense aquella capacitat de narrar-nos, esdevindríem bèsties. Ens és necessari el record, que ens uneix al llenguatge i, sobretot, a la consciència. Llavors s'imposa un projecte moral que exigeix imaginació, entusiasme, coratge, discerniment, sentit de la realitat, sentit de l'anticipació, voluntat de sobreviure... Un projecte que consistiria en la construcció d'un espai interior -el castell interior del qual parlava Teresa d'Àvila-, que regeix el sentit que atribuïm a l'experiència.

Per mitjà de la representació -derivada del pensament simbòlic- l'home biològic esdevé un subjecte moral. Aquest és l'home capaç de sotmetre's a unes normes. 


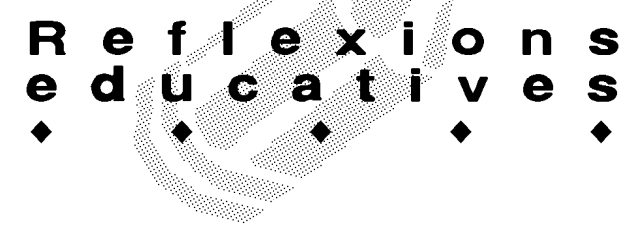

La capacitat normativa és el resultat de les emocions morals. De la mateixa manera que ens enamorem perquè hem sentit parlar de l'amor, per mitjà de la paraula que reconta les històries dels homes i les dones, aprenem a ésser justs, a estimar la bellesa, a ésser solidaris, a viure en llibertat... A assumir alguns dels valors, virtuts, deures i drets que, des dels presocràtics als postmoderns, la història del pensament ha anat consolidant i substanciant, alhora que configuren el patrimoni moral de la humanitat: la llibertat, la igualtat, la justícia, la pau, la solidaritat, la tolerància, el respecte per les persones i per la natura. No solament els valors d'eficàcia i productivitat. Aristòtil a l'Ética a Nicòmac diu que només som allò que fem, que ens definim per mitjà dels nostres actes. M'agradaria subratllar que les representacions del món que tenim el coratge d'imaginar també ens defineixen.

Era a l'estiu de 1816, a Ginebra, vora el llac Léman. Era un estiu plujós. Mary Shelley, tenia dinou anys, tot just casada i s'avorria. Escriví la història del doctor Frankenstein, entossudit d'arrabassar als déus un secret essencial: el secret de la generació de la vida. A partir d'aquest estrany personatge podem fer-nos algunes reflexions sobre l'educació. Frankenstein fabrica un home: l'imaginem amb el rostre cosit, el cos immens... I l'abandona a la seva sort. La criatura és fonamentalment bona, plena de bons sentiments, de compassió. Ignora els costums dels homes (Algú hi ha vist una representació del mite del bon salvatge: l'home natural que no ha conegut la societat). Però l'observa, el món, i se'n fa una representació. Se'l narra. Abandonada pel seu creador, la criatura intenta construir la seva pròpia educació. Descobreix el món a la manera de Locke i els filòsofs empiristes: prioritza l'experiència concreta. No hi ha res a la intel-ligència que abans no hagi passat pels sentits. Sent que algú llegeix "La vida dels homes il-lustres de Grècia i de Roma” de Plutarc, i escolta. Per mitjà d'aquelles històries descobreix els valors morals i socials. Ell sap que no és com Adam que va sortir perfecte de la mà de Déu, i era feliç, perquè el seu creador el protegia. Llavors se sent desemparat i sol, sotmès a les pròpies mancances enmig dels homes, que no el reconeixen com un dels seus.

D'aquest tema en podria parlar el doctor Jean Itard, que li costà fer un lloc a Víctor, el petit salvatge de l'Aveyron, dins la societat. En podria parlar L'home elefant, el film de David Lynch: la tenacitat fa que, malgrat les deficiències físiques, el "monstre" sigui reconegut com a membre de la comunitat dels homes i descoberta la seva humanitat. El doctor Frankenstein, en construir la seva criatura, havia cregut que podia fabricar un home i pensa que ha acabat la seva feina quan s'acaba el muntatge. Creu que pot posar un home al món sense acompanyar-lo en el món. Sense explicar-li que el món pot ésser representat i que és a través de la representació que arribem a comprendre'l. El mite de Frankenstein ve a dir-nos que un ésser humà és molt més que un collage d'elements físics i psíquics. L'educació ha de centrar-se en la relació de l'individu amb el món dels homes, amb el món de la cultura que l'acull.

L'home que narra s'humanitza alhora i penetra l'obscura matèria de què estan fets els somnis. També el teu propi relat interior t'humanitza. Què t'expliques a tu mateix de tu mateix? Quina història et contes a fi d'organitzar el teu propi caos?; perquè narrar també és posar ordre, configurar una història, organitzar-la, donar sentit al caos. I aquest és, ben segur, un dels motius pels quals als éssers humans els encanten les històries, car les històries són un tempteig d'ordenació d'aquells elements, sovint caòtics, que circulen entre els meandres oblidats de la ment.

He de dir que, quan utilitzo el verb encantar, vull referir-me a la influència irresistible que exerceixen les històries, en el sentit de fascinació. Als éssers humans els fascinen, i els captiven, i els plauen les històries. Els atreuen, perquè els produeixen plaer. De la mateixa manera que una serpent encanta l'ocell. Què li explica la serpent -només amb la mirada pot relatar-se, a vegades, una història-, mentre l'encanta?

\section{El relat oral}

Des que el món és món, les històries: vells romanços de cavallers errants, rondalles meravelloses, contes d'amor secret, històries picantioses i llegendes de sants, narracions de viatges, relats de vida: el servei militar, la nit de noces, la fastuosa història d'un oncle que partí mar endins i, àvid d'aventura, arribà a les terres quimèriques de l'or, apòlegs i comèdies d'enamoraments i alcavoteries, històries de la guerra civil que la gent ha contat durant anys en secret, mites que expliquen la creació del món... Des de l'horitzó remot del temps, les històries nodreixen la imaginació dels homes i ens diuen de manera eficaç que no ens trobem sols.

El vell relat oral, explicat durant segles a la vora del foc, al centre d'una plaça, a l'ombra porticada d'una església, en un mercat públic..., sorgeix amb nova saba cada vegada que un narrador s'atreveix a contar-lo de bell nou davant un auditori. El conte circula a l'interior del temps i abasta totes les cultures de la terra. S'ajusta a allò que els que l'escolten s'agraden de sentir, perquè és l'oïda del receptor que comanda el relat i elegeix entre les múltiples propostes que la història recontada desvetlla.

Podríem pensar, doncs, en el caràcter pluridimensional de la descodificació del missatge literari. Aquell 


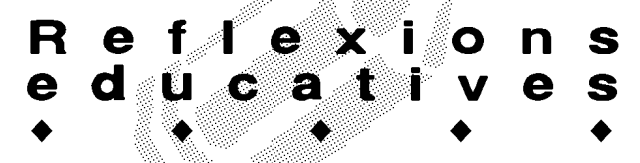

que escolta un conte, de la mateixa manera que aquell que el llegeix, efectua la seva pròpia interpretació; perquè el text conté diverses capacitats d'ésser llegit; però aquestes lectures estan profundament vinculades a la naturalesa intel-lectual del receptor, a la sensibilitat i als efectes de la seva personalitat sobre la lectura. Cal afirmar que la recepció literària a qualsevol edat depèn directament de les operacions mentals que el lector és capaç d'efectuar, estimulades pel contacte amb el text. Existeix una relació directa entre l'estructura mental d'un individu i la recepció que aquest individu farà del text literari. Però també sabem quines capacitats cognitives estimula i quin camí segueix l'experiència literària fins a transformar-se en experiència psíquica.

El text oral sorgeix de bell nou cada vegada que torna a ésser contat; però s'integren a la narració alguns elements que acompanyen la paraula poètica i la signifiquen: les modulacions de la veu, la melodia, l'energia dels gestos, la sonoritat dels mots, els silencis, activament fusionats en la configuració del sentit. Es tracta d'una veu que s'erotitza, alhora que narra. Paul Zumthor (1983) ha descrit aquesta experiència amb la paraula performance: una activitat complexa per mitjà de la qual un contingut poètic és simultàniament transmès i percebut en un espai i un temps irrepetibles. El receptor participa en l'acte creatiu i sap que es troba implicat en un acte únic, irreversible, efímer. Sap, també, que es tracta d'una experiència individual; perquè no és possible que la participació en el joc creatiu sigui experimentada de manera idèntica per diversos receptors. Però hem de saber que el component fonamental de la recepció és la capacitat del receptor de recrear l'univers significatiu que li és transmès. El ritme amb què Shéhérezade explica els seus contes -l'entonació que hi posa, la gestualitat, el silenci- no és estrany a allò que cerca obtenir de les històries que explica: el guany de viure. Perquè contar històries -representar la vida- equival a viure.

El secret de Shéhérezade és la capacitat d'escapar de la mort gràcies a la performance que teixeix al voltant dels relats: la tensió que crea, l'èmfasi que hi posa, la seva capacitat lúdica, l'enigma que fa girar sobre les paraules, la intemporalitat dels fets que són narrats. Una instància de simbolització - de recreació de l'univers significatiu que el conte transmet- significada per la veu. Es podria dir que la performance, dirigida a obtenir l'eficàcia textual, implica competència, no en el sentit de savoir-faire, sinó en el de savoir-être. Cal saber ésser, en la narració. Cal saber-hi estar. En la noció de performance hi trobarem sempre un element irreductible: la idea de presència del cos (ZUMTHOR, 1990). Llavors, la paraula i el gest esdevenen els canals a través dels quals s'efectua la comunicació poètica. I la poeticitat d'un text no solament consisteix en la capacitat de produir plaer, sinó també en la possibilitat d'actualitzarse en múltiples propostes, en una diversitat de lectures. Però allò que em sembla prodigiós és la seva capacitat de projectar la concreció d'una història més enllà del temps estricte de la comunicació. Cal afegir que la naturalesa de la performance afecta i modifica el missatge que ens és comunicat: per això és que ha de considerar-se una experiència cognitiva.

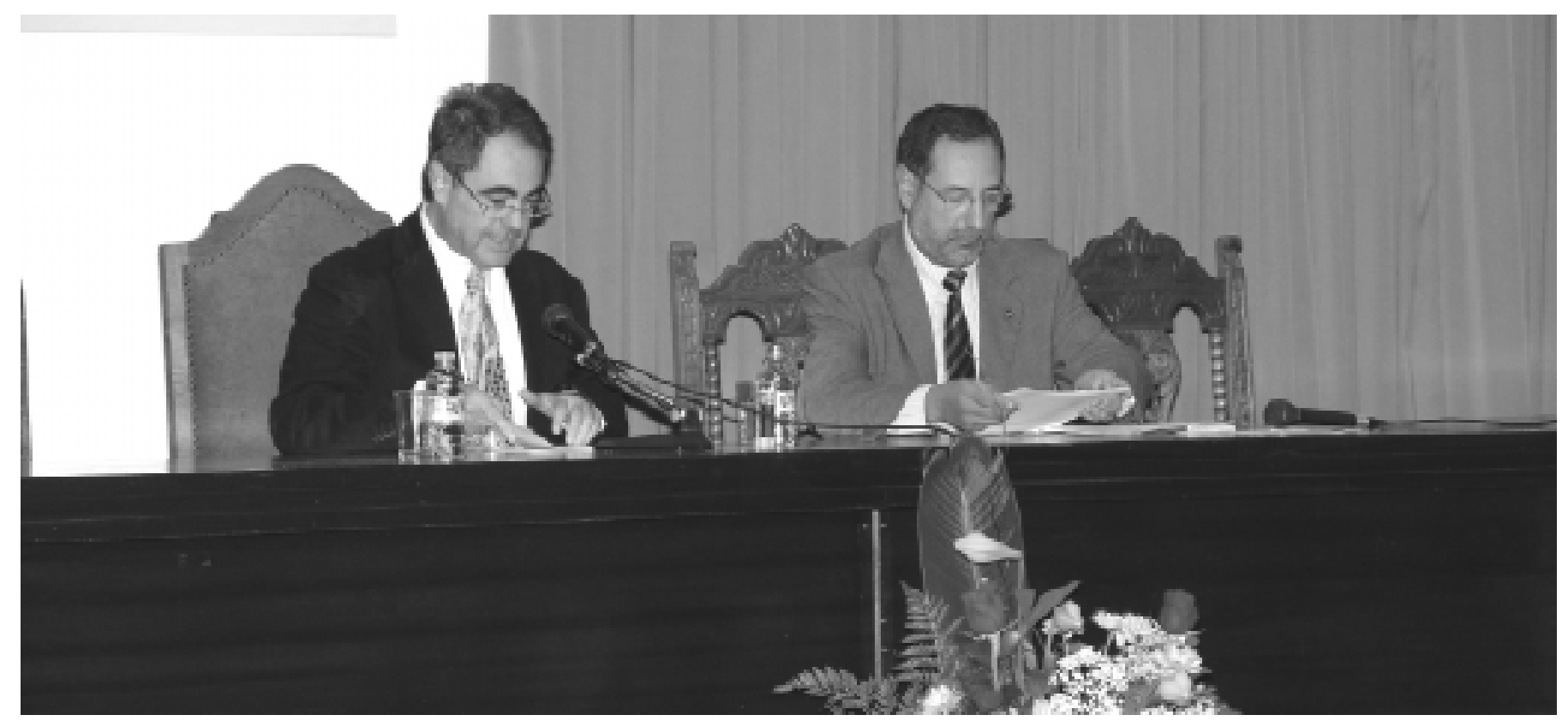




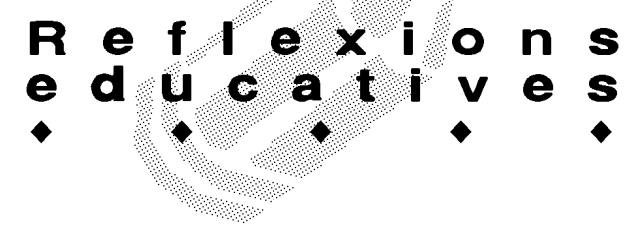

Mentre es produeix la narració oral, el narrador recrea la història i l'acompanya d'una teatralització que participa en la invenció de l'univers significatiu que emergeix del conte. La significació que adquireix el relat depèn d'aquell espai de ficció que configuren la veu -la ficció transita per la veu-, la capacitat de joc, la gestualitat, els múltiples matisos que donen forma i significat a les paraules.

\section{La capacitat de contar històries dels nins}

També la percepció dels textos escrits s'efectua a partir de les inquietuds del receptor, ha observat Hans Robert Jauss (1967) segons les vivències i les expectatives que configuren la seva visió particular del món (FIDALGO, 1991). La recepció literària, doncs, concreta -fa passar de la virtualitat a l'actualitat - quelcom que el receptor reconeix.

La capacitat de contar històries comença durant els primers anys de la vida. Narrar és per a un nin de quatre anys un joc, amb tot el que de llibertat i invenció fantàstica conté el joc. També ho és escoltar una història. Mitjançant la narració obté alguns beneficis fonamentals: primerament, explica les històries que imagina, a l'interior de les quals experimenta realitats fictícies i tresca paisatges inèdits; en segon lloc, aprèn a construir històries significatives, narracions proveïdes de significat. He dit abans que la manera d'emmarcar l'experiència, si no volem que es perdi més enllà del record, és a través d'una estructura narrativa. El nin aprèn a utilitzar alguns instruments narratius a fi d'obtenir aquelles coses que vol. Aprèn, sobretot, a justificar la narració dels fets amb la intenció d'evitar la confrontació i el conflicte, a contar la història sota la llum de la legitimitat i relatar-la amb totes les circumstàncies atenuants. Negocia el significat, alhora que aprèn -la cultura posa al seu abast un seguit de recursos narratius $i$ una sèrie de tècniques d'interpretació- a conèixer els processos mitjançant els quals es negocien els significats en el context d'una determinada comunitat (BRUNER, 1991). Aprèn que la significació és múltiple i divergent, alhora; que els nostres actes es troben profundament afectats per la manera en què contam allò que hem fet. I descobreix que la narració depèn del poder de les figures retòriques: de la metàfora, la metonímia, la sinècdoque, la implicació... Sense el concurs d'aquestes figures la narració perdria la capacitat d'amplificació: el poder d'explorar les connexions que existeixen entre el que és quotidià i l'insòlit. La capacitat que tenim els éssers humans de compartir històries que parlen de la diversitat de la vida i d'interpretar-les de manera congruent amb els compromisos morals de la societat en què vivim constitueix una de les formes més poderoses d'estabilitat social.
Per a l'home del final d'aquest segle, la representació de la vida que ens ofereix la ficció literària respon a una necessitat d'entendre més que de conèixer. El cos s'hi abriga, perquè és una veu que fa bon escoltar, a través de la qual pot encara trobar-se una sensibilitat sovint ignorada. Possiblement, allò que en la performance oral és una realitat que s'experimenta, es troba en la lectura en l'ordre del desig. El lector desitja acostar-se a aquella veu misteriosa que li indica que no es troba sol. És la veu de l'autor que l'ajuda en la recerca de possibles significats. I és la indeterminació del text allò que incita el lector a participar en l'aventura de la construcció del sentit. És el caire salvatge de la lectura, de descoberta, d'aventura, l'aspecte necessàriament inacabat $\mathrm{i}$ incomplet. Com succeeix amb tots els plaers: sempre queda un espai misteriós que no ens atrevim a penetrar.

En un conte que recull Stith Thompson (1946) i que explica la creació de l'home, s'especifiquen els materials de què era fet Adam: el tronc era d'argila; els ossos, de pedra; les venes, d'arrels; la sang era d'aigua; els cabells eren d'herba; el pensament era de vent i l'esperit, de núvols. Potser el narrador remot que inventà aquest relat volgué significar la fragilitat borrascosa de les fabulacions que teixeix el vent de la memòria a l'interior de les quals circulen els núvols que produeix el cor.

Cada dia la premsa escrita, la televisió, la ràdio ens parlen d'Europa. Algú ha escrit que Bòsnia és el gran fracàs d'Europa -si més no, el gran fracàs moral-i que ésser europeu és una vergonya. Però cal proclamar encara la necessària tolerància, la comprensió, la reivindicació de la diversitat... Cal construir Europa com un espai de llibertat on totes les diversitats siguin possibles. Fa algun temps vaig llegir una definició bellíssima d'Europa; però era una mentida. Deia: Europa és aquella terra on ja no existeix la pena de mort. Potser no és així; però podria interpretar-se que només són Europa aquelles terres on la pena de mort no existeix.

Fa devers cinc anys que vaig assistir al festival internacional de teatre de titelles de Charleville-Mézières a la regió de les Ardenes, al cor de l'Europa del nord. Un grup de Sarajevo, les actuacions del qual eren esperades amb inquietud, no havia pogut arribar d'hora perquè no permetien que sortís del seu país en guerra i l'actuació hagué de demorar-se fins al darrer dia, en què, finalment, la companyia pogué fer les seves representacions, ja a punt de clausurar-se la mostra. Jo hi era, aquella tarda, a la sala. Un actor s'aproximà al públic $i$ explicà que l'espectacle que veuríem l'havien vist, abans que nosaltres, molts de nins i nines d'aquella ciutat cremada per la duresa de la guerra, reclosos en hospitals i orfenats. $\mathrm{Si}$ alguna vegada hem aconseguit -afirmà aquell actorque sorgís un somriure sobre els seus llavis, ja ens 


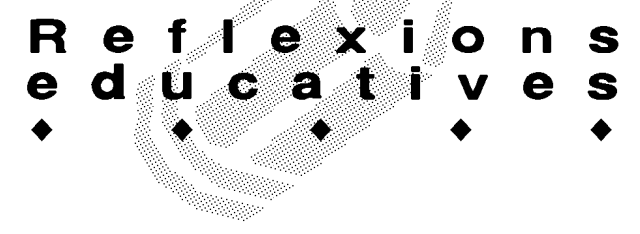

donem per conhortats. Era un espectacle que feia de la tendresa i el joc la seva poètica, proveïda a voltes d'un cert humor. Els actors cantaven una cançó popular de la seva terra. Era una cançó de mariners que parlava d'una nau perduda. Ens havien donat una barca de paper de diari que portava notícies de la guerra. I us asseguro que des del primer gest havien aconseguit crear un sentiment de complicitat extraordinària: convocar la solidaritat dels espectadors amb aquells nins i nines dels hospitals i orfenats de Sarajevo que potser havien somrigut davant aquell teatre. Vaig pensar en Europa, aquest projecte que cal redefinir contínuament a partir dels seus drames.

\section{La tasca del procés educatiu}

I vaig pensar en la gran tasca que correspon a l'educació. No fa gaire un pedagog i un periodista francesos, Philippe Meirieu i Marc Guiraud han publicat un llibre amb aquest títol: L'escola o la guerra civil, en el sentit que, o bé redefinim els objectius i el funcionament de l'escola (una nova escola basada en l'educació cívica i la democràcia, contra la competitivitat que provoca la selecció abusiva, l'apartheid, l'analfabetisme i el fracàs) o podem arribar a construir una societat de mafiosos $\mathrm{i}$ sectària, dirigida a la confrontació civil. Educar perquè siguem capaços d'existir. Vet aquí el repte: existir des de la diferència; però des del pacte social que això comporta.

Hem utilitzat sovint, com a indicadors de la identitat d'un poble - del nostre poble-, la llengua, la història, la cultura... La cultura com a relació dels homes amb un determinat espai. Llavors hem parlat d'herència social i de concepció del món. Sabem que la cultura és acumulativa, que complementa l'herència biològica, que es constitueix en norma de conducta, en ideal que orienta la vida de la comunitat. Els estructuralistes distingien la cultura com a sistema universal significant i, d'ençà del model lingüístic de Saussure, la cultura com a sistema abstracte (llengua) $i$ les cultures que es concreten en diversos espais (parla). I també sabem que la cultura és una necessitat biològica de tots els humans: aquesta necessitat és, doncs, un universal que es concreta en múltiples existències que l'educació ha de promoure. Identitat i consciència col-lectiva també vol dir identitat i procés de cohesió. És necessari que la cultura -al capdavall és una representació del món- ens identifiqui, però cal promoure processos de cohesió. I cohesió no vol dir uniformitat; perquè allò que ens cohesiona és la diversitat de significats que coexisteixen en un determinat espai.

Des d'aquesta perspectiva antropològica de l'educació es podria arribar a una definició del procés educatiu: el procés, doncs, a través del qual un ésser humà construeix la seva particular representació del món. La peripècia per mitjà de la qual aprenem a atribuir significat a la vida. I podria ésser un diàleg, l'educació, entre el nin que aprèn a construir conceptualment el món i l'adult que el guia i li facilita les eines. Però la identitat no és una realitat estàtica, sinó dinàmica, com ho són les cultures. Cal aprofundir en els elements que defineixen la identitat d'un poble tot reconeixent el seu caràcter dinàmic que segueix atractius processos d'evolució, de reinterpretació, de selecció -les cultures tenen tants d'elements adquirits per selecció, afirmava K. Lorenz, com les espècies-, d'innovació... I conèixer els rituals d'iniciació, les capacitats d'enculturació de les societats urbanes, definir l'etnicitat urbana i els processos d'adaptació, concebre la cultura com una realitat en construcció permanent i preveure'n les conseqüències educatives...

La defensa de l'especificitat cultural contra la uniformitat deriva cap a la reivindicació de la diferència. Llavors es podria parlar de la incorporació al desenvolupament comú -al projecte d'Europa- dels elements de la pròpia especificitat.

A vegades penso que no és fàcil per a l'adult del nostre temps, que ha renunciat a tantes utopies i ha derivat en la resignació, transmetre als infants, als adolescents i als joves allò en què ja no creu. Sé, emperò, que ens és necessari repensar la possibilitat d'una vida més justa, perquè ens dóna la força i la capacitat de lluita. Els nostres alumnes ens obliguen a pensar allò que ens agradaria fer del món, el sentit que voldríem atribuir al nostre país. Cada dia els nostres alumnes ens inciten a la coherència.

\section{Referències bibliogràfiques}

BRUNER, Jerome. Actos de significado. Más allá de la revolución cognitiva. Alianza Editorial. Madrid. 1991.

CHARTIER, Roger. Narración y verdad. Temas de nuestra época. EL PAÍS. Madrid. 29-VII-1993. Pàgs. 3-4.

FIDALGO, Segundo. Leer y crear. «CLIJ (Cuadernos de Literatura Infantil y Juvenil)», 25 (1991).

JAUSS, Hans Robert. Literaturgeschichte als Provokation der Literaturwissenschaft. Edit. Universitäts-Durckerei. Konstanz. 1967.

SPIEGEL, Gabrielle M. Huellas de significado. La literatura histórica en la era del posmodernismo. Temas de nuestra época. EL PAís. Madrid. 29-VII-1993. Pàgs. 4-5.

THOMPSON, Stith. The Folktale. Edit. Holt, Rinchart and Winston, Inc. New York. 1946.

ZUMTHOR, Paul. Introduction à la poésie orale. Edit. du Seuil. París. 1983.

ZUMTHOR, Paul. Performance, réception, lecture. Edit. Le Préambule. Québec. 1990. 